\title{
Aplikasi Pupuk Bokashi Padat Berbahan Dasar Feses Babi dengan Level Berbeda terhadap Pertumbuhan Tanaman Sengon Laut (Paraserianthes falcataria (L.) Nielsen)
}

\section{Patrisius Klau ${ }^{\text {a }}$, Stefanus Sio ${ }^{\text {b }}$ Polikarpia W. Bani}

${ }^{a}$ Fakultas Pertanian, Universitas Timor, Kefamenanu, TTU - NTT, Indonesia email: patrisiusklau6@gmail.com

${ }^{b}$ Fakultas Pertanian, Universitas Timor, Kefamenanu, TTU - NTT, Indonesia, email: stefsio67@gmail.com

${ }^{c}$ Fakultas Pertanian, Universitas Timor, Kefamenanu, TTU - NTT, Indonesia, email: helmi_bani@yahoo.com

\section{Article Info}

\section{Article history:}

Received 30 Januari 2019

Received in revised form 4 Maret 2019

Accepted 5 April 2019

DOI

https://doi.org/10.32938/ja.v4i2.644

\section{Keywords:}

Bokashi

Pertumbuhan

Sengon Laut

\begin{abstract}
Abstrak
Penelitian bertujuan untuk mengetahui pengaruh aplikasi pupuk bokashi padat berbahan dasar feses babi dengan level berbeda terhadap pertumbuhan tanaman sengon laut. Penelitian menggunakan rancangan acak lengkap (RAL) yang terdiri dari 4 perlakuan dan 3 ulangan dan setiap ulangan terdiri dari 5 sehingga terdapat 60 polibag. $\mathrm{R}_{0}=$ Tanpa pemberian Bokashi (kontrol), $\mathrm{R}_{1}=$ Aplikasi Bokashi 500 $\mathrm{g} /$ polibag, $\mathrm{R}_{2}=$ Aplikasi Bokashi $750 \mathrm{~g} /$ polibag, $\mathrm{R}_{3}=$ Aplikasi Bokashi $1000 \mathrm{~g} / \mathrm{polibag}$. Variabel yang diamati yaitu tinggi tanaman, tangkai daun. Hasil penelitian menunjukan bahwa pemberian bokashi padat pada level $1000 \mathrm{~g} /$ polibag secara signifikan mempengaruhi tinggi tanaman yaitu sebesar $12,43 \mathrm{~cm}$, jumlah tangkai daun 9,93 tangkai, diameter batang $0,74 \mathrm{~mm}$. Disimpulkan penelitian ini adalah Pemberian pupuk Bokashi padat berbahan dasar feses babi sangat efektif dalam meningkatkan nilai kesuburan tanah sehingga dapat meningkatkan pertumbuhan tanaman sengon laut dengan bertambahnya tinggi tanaman, jumlah tangkai daun dan diameter batang dan Pemberian pupuk Bokashi padat berbahan dasar feses babi pada level $1000 \mathrm{~g}$ (R3) memberikan hasil terbaik pada tinggi tanaman sebesar $12,43 \mathrm{~cm} / \operatorname{tanaman}$; Jumlah tangkai daun 9,93 tangkai/tanaman dan diameter batang sebesar $0,74 \mathrm{~cm} / \operatorname{tanaman}$. Hasil ini lebih baik dibandingkan perlakuan level Bokashi $500 \mathrm{~g}$ (R1), $750 \mathrm{~g}$ (R2) maupun Kontrol (R0).
\end{abstract}

\section{Pendahuluan}

Pengembangan subsektor peternakan merupakan salah satu program pemerintah dalam rangka mendukung upaya swasembada pangan melalui penyediaan daging, telur dan susu serta produk lainnya yang bersumber dari produk peternakan. Tujuan tersebut akan tercapai jika semua faktor pendukung dapat bersinergi melalui manajemen yang tepat dan terarah. Salah satu fakto yang sangat penting dalam usaha budidaya peternakan adalah melalui penyediaan pakan ternak dengan memperhatikan aspek kualitas, kuantitas dan keberlanjutannya.

Sengon Laut (Paraserianthes falcataria (L.) Nielsen) merupakan salah satu jenis tanaman kehutanan yang diminati oleh masyarakat karena memiliki nilai ekomoni yang cukup tinggi sehingga banyak dikembangkan oleh masyarakat di Indonesia. Pada umumya, sengon laut dikembangkan masyaraka dalam bentuk hutan rakyat sebagai penaung pada tanaman perkebunan, maupun tanaman monokultur karena pertumbuhannya sangat cepat-mencapai $7 \mathrm{~m}$ dalam setahun (Anggraeni \& Lelana, 2011). Selain itu, tanaman sengon laut mampu beradaptasi pada berbagai kondisi tanah, mempunyai karakter silvikultur yang baik, serta batangnya dapat digunakan sebagai bahan industri panel dan berbagai industri pertukangan (Krisnawati et al., 2011).

Budidaya tanaman sengon laut dilahan kering menjadi tantangan pada umumnya rendahnya kelembapan dan tingginya suhu lingkungan dengan kondisi seperti ini menyebabkan sengon laut tidak dapat bertahan dalam kondisi kekeringan sehingga menyebabkan rendahnya produksi dan kualitas nutris tanaman. Dalam memanfaatkan unsur hara kurang efisien air didalam tanah yang tersedia.

Daun sengon laut, sebagaimana famili Leguminoceae lainnya, merupakan pakan ternak yang sangat baik dan mengandung protein tinggi Jenis ternak seperti sapi, kerbau, dan kambing menyukai daun sengon lau tersebut. Selain sebagai pakan ternak, daun sengon laut yang berguguran akan menjadi pupuk hijau yang baik bagi tanah dan tanaman disekitarnya. Sementara itu, tajuk pohonnya yang besar dan rindang sudah sejak lama dimanfaatkan sebagai pohon penaungan dibeberapa area perkebunan (Siregar, 2008).

Peningkatan nilai kesuburan tanah pada lahan kering dapat ditempuh dengan penerapan teknologi melalui kegiatan pemupukan dengan tujuan menyediakan unsur hara bagi tanaman. Pada tahap pertumbuhan dan perkembangannya, tanaman sengon laut membutuhkan unsur hara. Unsur hara dapat diasup dari beberapa jenis pupuk organik seperti Bokashi. Bokash merupakan pupuk organik yang kaya akan hara seperti N, P, K, C, KCL. Selain sebagai bahan makanan bagi tanaman unsur hara juga berperan dalam membentuk kondisi yang ideal pada tanah sehingga mikroorganisme tanah dapat tumbuh dan berkembang. Adapun kandungan Bokashi terdiri dari: $\mathrm{N}$ $1,25 \%$, P: $1,02 \%$, K: 1,44\%, KCL: $7,60 \%$, H20: $8,50 \%$, C: $26,90 \%$ (Musayyanah, 2010). Pembuatan pupuk Bokashi tergolong sederhana dan tidak membutuhkan biaya yang mahal, namun teknologi ini belum dikenal oleh banyak kalangan peternak mengingat akses informasi yang masih terbatas pada masyarakat peternak

Aplikasi pupuk Bokashi dapat memperbaiki struktur tanah, meningkatkan kapasitas menahan air, dan meningkatkan kehidupan biolog tanah. Lebih jauh Acquaah (2005) menyatakan bahwa bahan organik Bokashi berperan penting dalam meningkatkan kesuburan tanah melalui perbaikan sifa fisik, kimia, dan biologis tanah karena hasil fermentasi bahan organik yang dilakukan oleh mikroorganisme efektif (EM) adalah asam laktat, asam amino, yang dapat diserap langsung oleh tanaman sebagai antibiotik yang mampu menekan pertumbuhan mikroorganisme yang merugikan.

Penggunaan Bokashi berbahan dasar feses babi maupun mikroorganisme efektif telah diteliti dan pada umumnya hasilnya positif, termasuk pengaruh positif bahan organik pupuk Bokashi telah dilaporkan pada produksi, jagung manis (Mayadewi, 2007). Hingga saat ini pemanfaatan Bokashi kotoran babi belum banyak diaplikasikan pada lahan kering, seperti di TTU terutama dalam hal pembudidayaan tanaman pakan ternak.

\section{Metode}

Penelitian ini telah dilaksanakan pada kebun percobaan Fakultas Pertanian, Universitas Timor, Kelurahan Sasi, Kecamatan Kota Kefamenanu, Kabupaten TTU selama 2 bulan dimulai dari bulan Agustus sampai Oktober 2018. Rancangan yang digunakan dalam penelitian ini adalah rancangan acak lengkap (RAL) yang terdiri dari 4 perlakuan dan 3 ulangan dan setiap ulangan terdiri dari 5 sehingga terdapat 60 polibag.

$\mathrm{R}_{0}=$ Tanpa pemberian Bokashi (kontrol)

$\mathrm{R}_{1}=$ Aplikasi Bokashi $500 \mathrm{~g} /$ polibag

$\mathrm{R}_{2}=$ Aplikasi Bokashi $750 \mathrm{~g} /$ polibag

$\mathrm{R}_{3}=$ Aplikasi Bokashi $1000 \mathrm{~g} /$ polibag

Pembuatan pupuk Bokashi dengan cara larutan EM4 dan gula air yang telah tersedia, dilarutkan dalam wadah yang berisi air bersih dengan perbandingan EM4 $250 \mathrm{ml}$ dan 20 liter air bersih. Bahan-bahan yang telah tersedia seperti hijauan, terlebih dahulu dicincang sampai halus lalu dicampur merata dengan feses babi, sekam padi dan dedak di tempat yang telah ditentukan dan dalam penelitian ini menggunakan terpal untuk proses fermentasi. Selanjutnya, adonan di sirami larutan EM4 + gula air yang telah disiapkan, sambil dibalik agar merata dan digundukan setinggi $15-20 \mathrm{~cm}$ diatas terpal. Kemudian ditutup rapat menggunakan terpal untuk proses fermentasi. Hal yang perlu diperhatikan selama proses fermentasi adalah suhu maksimal \pm $45^{\circ} \mathrm{C}$, bila suhunya lebih maka diturunkan dengan cara membalik sambi dipercik dengan air. Menunggu hingga 2 minggu maka proses fermentasi telah selesai dan pupuk Bokashi siap digunakan. Variabel yang dilihat adalah tingg tanaman, diameter batang dan jumlah tangkai daun yang diambil sebanyak 4 kali (15 Hari Setelah Tanam HST), 30 HST, 45 HST dan 60 HST). Data yang diperoleh dianalisis dengan menggunakan analisis sidik ragam dan dilanjutkan dengan uji ducan untuk melihat perbedaan antara perlakuan menurut Steel and Torrie (1995)

\section{Hasil dan Pembahasan}

\subsection{Tinggi Tanaman}

Tinggi tanaman merupakan salah satu parameter yang digunakan untuk mengukur pertumbuhan turi. Hasil pengukuran terhadap tinggi tanaman selama penelitian dapat dilihat pada Tabel 1 .

Berdasarkan Tabel 1 memperlihatkan tinggi tanaman tanpa pemberian pupuk bokashi (R0) pada hari ke 60 HST dengan rata-rata sebesar 7,15 dan pemberian pupuk bokashi padat dengan level berbeda pada hari ke 60 HST dengan rata-rata $500 \mathrm{~g}(\mathrm{R} 1)=7,71,750(\mathrm{R} 2)=9,98$ dan $1000(\mathrm{R} 3)=12.43$ Tinggi tanaman yang terendah terdapat pada perlakuan kontrol atau tanpa pemberian pupuk bokashi padat yaitu $7,15 \mathrm{~cm}$ yang tertinggi didapatkan pada perlakuan pemberian pupuk bokashi padat $1000 \mathrm{~g}(\mathrm{R} 3)$ yaitu $12,43 \mathrm{~cm}$. Tingg tanaman yang lebih tinggi pada perlakuan dengan pemberian pupuk bokashi padat $1000 \mathrm{~g}$, karena pupuk bokashi padat yang digunakan mengandung unsur hara terutama $\mathrm{N}$ yang berperan dalam memacu pertumbuhan tanaman secara umum, terutama pada fase vegetatif, pembentukan klorofil, asam amino, lemak, enzim, dan persenyawaan lain. Hormon yang berperan adalah auksin dan giberelin yang berfungsi sebagai penyusun protein, perpanjangan sel, mempengaruhi pemanjangan batang yang dibutuhkan tanaman untuk pertumbuhan terutama pertumbuhan vegetatif (Lingga dan Marsono 2004). Semakin tercukupinya kebutuhan $\mathrm{N}$ yang diberikan maka pertambahan tingg tanaman juga akan semakin maksimal. Lingga dan Marsono (2004), menyatakan bahwa terjadinya pertumbuhan tinggi dari suatu tanaman disebabkan karena adanya peristiwa pembelahan dan perpanjangan sel yang di 
dominasi pada ujung pucuk tanaman tersebut. Proses ini merupakan sintesa protein yang diperoleh tanaman dari lingkungan seperti bahan organik dalam tanah. Penambahan bahan organik yang mengandung $\mathrm{N}$ akan mempengaruhi kadar $\mathrm{N}$ total dan membantu sel-sel tanaman dan mempertahankan jalannya proses fotosintesis yang pada akhirnya pertumbuhan tinggi tanaman dapat dipengaruhi.

Tabel 1. Tinggi Tanaman 15, 30, 45 dan 60 Hari Setelah Tanam

\begin{tabular}{|c|c|c|c|c|}
\hline \multirow{2}{*}{$\begin{array}{c}\text { Waktu } \\
\text { Pengamatan } \\
\text { (HST) }\end{array}$} & \multicolumn{4}{|c|}{ Bokashi (kg) } \\
\hline & R0 (Kontrol) & R1 (500g) & R2 (750g) & R3 (1000g) \\
\hline \multirow{3}{*}{15} & 4.02 & 4.48 & 4.44 & 4.88 \\
\hline & 3.96 & 4.28 & 4.4 & 4.94 \\
\hline & 4.12 & 4.28 & 4.42 & 4.72 \\
\hline Rerata & $4.03^{c}$ & $4.35^{b}$ & $4.42^{b}$ & $4.85^{a}$ \\
\hline \multirow{3}{*}{30} & 5.16 & 5.64 & 5.52 & 6.32 \\
\hline & 5.24 & 5.42 & 5.84 & 6.82 \\
\hline & 4.68 & 5.22 & 5.94 & 6.06 \\
\hline Rerata & $5.03^{a}$ & $5.43^{\mathrm{bc}}$ & $5.77^{b}$ & $6.40^{a}$ \\
\hline \multirow{3}{*}{45} & 6.1 & 6.44 & 7.62 & 9.94 \\
\hline & 6.3 & 6.10 & 7.42 & 8.8 \\
\hline & 6.1 & 6.64 & -7.58 & 9.02 \\
\hline Rerata & $6.17^{c}$ & $6.39^{c}$ & $7.54^{b}$ & $9.25^{a}$ \\
\hline \multirow{3}{*}{60} & 7.06 & 7.82 & 9.68 & 14.34 \\
\hline & 7.22 & 7.58 & 10.32 & 12.6 \\
\hline & 7.18 & 7.74 & 9.94 & 10.36 \\
\hline Rerata & $7.15^{c}$ & $7.71^{c}$ & $9.98^{b}$ & $12.43^{\mathrm{a}}$ \\
\hline
\end{tabular}

\subsection{Jumlah Tangkai Daun}

Tanaman yang diberikan bokashi padat 1000 gr cenderung meningkatkan jumlah tangkai daun dibanding tanaman yang diberikan bokashi 500 gr, 750 gr dan kontrol. Hasil sidik ragam (anova) menunjukkan pengaruh nyata antar perlakuan terhadap jumlah tangkai daun dapat di lihat pada Tabel 2.

Tabel 2. Jumlah Tangkai Daun 15, 30, 45 dan 60 Hari Setelah Tanam

\begin{tabular}{|c|c|c|c|c|}
\hline \multirow{2}{*}{$\begin{array}{c}\text { Waktu Pengamatan } \\
\text { (HST) }\end{array}$} & \multicolumn{4}{|c|}{ Bokashi (kg) } \\
\hline & R0 (Kontrol) & R1 (500g) & R2 (750g) & R3 (1000g) \\
\hline \multirow{3}{*}{15} & 4 & 4.00 & 4 & 3.8 \\
\hline & 3.4 & 4.00 & 4 & 3.8 \\
\hline & 3.6 & 4.00 & 3.8 & 4 \\
\hline Rerata & $3.67^{a}$ & $4.00^{a}$ & $3.93^{a}$ & $3.87^{\mathrm{a}}$ \\
\hline \multirow{3}{*}{30} & 5.8 & 5.80 & 5.2 & 5.8 \\
\hline & 4.8 & 5.20 & 5.2 & 5.4 \\
\hline & 5.2 & 5.20 & 4.6 & 5.2 \\
\hline Rerata & $5.27^{\mathrm{a}}$ & $5.40^{\mathrm{a}}$ & $5.00^{a}$ & $5.47^{\mathrm{a}}$ \\
\hline \multirow{3}{*}{45} & 7.2 & 6.20 & 6.6 & 7.6 \\
\hline & 5.8 & 7.00 & 6.2 & 8.4 \\
\hline & 6.6 & 6.80 & 6.6 & 7.6 \\
\hline Rerata & $6.53^{b}$ & $6.67^{b}$ & $6.47^{b}$ & $7.87^{a}$ \\
\hline \multirow{3}{*}{60} & 8 & 7.20 & 8.6 & 10 \\
\hline & 7 & 8.20 & 8.2 & 10.2 \\
\hline & 7.6 & 7.80 & 8.4 & 9.6 \\
\hline Rerata & $7.53^{b}$ & $7.73^{b}$ & $8.40^{b}$ & $9.93^{a}$ \\
\hline
\end{tabular}

Keterangan: Angka yang diikuti superscript yang sama menunjukan tidak berbeda nyate $(P>0,05)$ pada $\propto 0,05$

Berdasarkan Tabel 2 memperlihatkan jumlah tangkai daun tanpa pemberian pupuk bokashi (R0) pada hari ke 60 HST dengan rata-rata sebesar 7,53 dan pemberian pupuk bokashi padat dengan level berbeda pada hari ke 60 HST dengan rata-rata $500 \mathrm{~g}(\mathrm{R} 1)=7,73,750 \mathrm{~g}(\mathrm{R} 2)=8,40$ dan $1000 \mathrm{~g}(\mathrm{R} 3)=$ 9,93. Jumlah tangkai daun paling sedikit terdapat pada perlakuan kontrol atau tanpa pemberian pupuk bokashi padat yaitu $7,53 \mathrm{~cm}$ dan jumlah tangkai daun yang paling banyak didapatkan pada perlakuan pemberian pupuk bokashi padat $1000 \mathrm{~g}$ (R3) yaitu 9,93 cm. Hal ini karena pemberian pupuk bokashi padat 1000 g mampu meningkatkan pembelahan sel membentuk daun baru sehingga jumlah tangkai daun yang dihasilkan berbeda. Pemberian pupuk bokashi padat dapat meningkatkan ketersedian unsur hara $\mathrm{N}$ dan $\mathrm{K}$ pada tanah sehingga dapat memacu pertumbuhan jumlah tangkai daun. Hormon yang berperan adalah hormon sitokinin yang berfungsi membantu proses pertumbuhan akar dan tunas, memperkecil dominansi apikal dan juga dapat menyebabkan pembesaran daun mudah, merangsang pembelahan sel dengan cepat dan memperlambat terjadinya pengguguran daun, bunga dan buah pada tumbuhan karena terjadi peningkatan transport makanan. Unsur hara $\mathrm{N}$ dapat berperan dalam memacu pertumbuhan tanaman secara umum, terutama pada fase vegetatif, berperan dalam pembentukan klorofil, asam amino, lemak, enzim, dan persenyawaan lain. Menurut pendapat Poerwowidodo (2008) yang menyatakan unsur hara K salah satu unsur kimia, berperan dalam meningkatkan toleransi terhadap kondisi kering karena mampu mengontrol stomata daun sehingga transpirasi dapat dikendalikan. Unsur K berperan dalam mengaktifkan pembentukan bulubulu akar dan biji serta menguatkan batang, pembentukan protein dan karbohidrat, memperkuat tubuh tanaman agar daun, bunga dan buah tidak mudah gugur.

\subsection{Diameter Batang}

Tanaman yang diberikan pupuk bokashi padat 1000 gr cenderung meningkatkan diameter batang dibanding tanaman yang diberikan bokashi padat 500 gr, 750 gr dan kontrol. Hasil sidik ragam (anova) menunjukkan pengaruh nyata antar perlakuan terhadap diameter batang dapat di lihat pada Tabel 3.

Tabel 3. Diameter Batang 15, 30, 45 dan 60 Hari Setelah Tanam

\begin{tabular}{|c|c|c|c|c|}
\hline \multirow{2}{*}{$\begin{array}{c}\text { Waktu } \\
\text { Pengamatan } \\
(\text { HST) } \\
\end{array}$} & \multicolumn{4}{|c|}{ Bokashi (kg) } \\
\hline & R0 (Kontrol) & R1 (500g) & R2 (750g) & R3 (1000g) \\
\hline \multirow{3}{*}{15} & 0.24 & 0.30 & 0.42 & 0.44 \\
\hline & 0.26 & 0.30 & 0.36 & 0.44 \\
\hline & 0.24 & 0.30 & 0.36 & 0.44 \\
\hline Rerata & $0.25^{d}$ & $0.30^{c}$ & $0.38^{b}$ & $0.44^{\mathrm{a}}$ \\
\hline \multirow{3}{*}{30} & 0.34 & 0.40 & 0.52 & 0.54 \\
\hline & 0.36 & 0.40 & 0.46 & 0.54 \\
\hline & 0.34 & 0.40 & 0.46 & 0.54 \\
\hline Rerata & $0.35^{d}$ & $0.40^{\mathrm{c}}$ & $0.48^{b}$ & $0.54^{a}$ \\
\hline \multirow{3}{*}{45} & 0.44 & 0.48 & 0.62 & 0.64 \\
\hline & 0.46 & 0.50 & 0.54 & 0.64 \\
\hline & 0.44 & 0.50 & 0.56 & 0.64 \\
\hline Rerata & $0.45^{c}$ & $0.49^{c}$ & $0.57^{b}$ & $0.64^{\mathrm{a}}$ \\
\hline \multirow{3}{*}{60} & 0.54 & 0.58 & 0.72 & 0.74 \\
\hline & 0.56 & 0.60 & 0.64 & 0.74 \\
\hline & 0.54 & 0.60 & 0.66 & 0.74 \\
\hline Rerata & $0.55^{c}$ & $0.59^{c}$ & $0.67^{b}$ & $0.74^{a}$ \\
\hline
\end{tabular}

Berdasarkan Tabel 3. terlihat bahwa diameter batang tanpa pemberian pupuk bokashi (R0) pada hari ke 60 HST dengan rata-rata sebesar 0,55 dan pemberian pupuk bokashi padat dengan level berbeda pada hari ke $60 \mathrm{HST}$ dengan rata-rata $500 \mathrm{~g}(\mathrm{R} 1)=0,59,750 \mathrm{~g}(\mathrm{R} 2)=0,67$ dan $1000 \mathrm{~g}(\mathrm{R} 3)=0,74$ Diameter batang terendah terdapat pada perlakuan kontrol atau tanpa pemberian pupuk bokashi padat yaitu $0,55 \mathrm{~cm}$ dan diameter batang yang paling tinggi didapatkan pada perlakuan pemberian pupuk bokashi padat $1000 \mathrm{~g}$ yaitu $0,74 \mathrm{~cm}$. Perbedaan diameter batang yang dihasilkan antara perlakuan dengan kontrol karena adanya aktivitas pembelahan dan perbesaran sel pada meristem lateral yang mengakibatkan diameter batang menjadi lebih besar. Sesuai dengan pendapat Sarief (2015) yang menyatakan bahwa ketersediaan unsur hara yang dapat diserap oleh tanaman merupakan salah satu faktor yang mempengaruhi pertumbuhan tanaman yang akan menambah pembesaran sel yang berpengaruh pada diameter batang. Unsur hara yang berperan dalam diameter batang adalah unsur $\mathrm{N}$ yang berperan dalam memacu pertumbuhan tanaman secara umum, terutama pada fase vegetatif, berperan dalam pembentukan klorofil, asam amino, lemak, enzim, dan persenyawaan lain. Hormon yang berperan adalah hormon giberelin dan sitokinin karena hormon giberelin dan sitokinin berfungsi sebagai pemanjangan dan pembelahan sel, pemanjangan batang, mempengaruhi pembengkokan batang dan mempengaruhi pertumbuhan dan perkembangan akar, daun, bunga dan buah khususnya pada tanaman yang lebih muda sehingga dengan adanya unsur hara $\mathrm{N}$ dapat mendorong pertumbuhan vegetatif tanaman diantaranya pembentukan klorofil pada daun sehingga akan memacu laju fotosintesis. Semakin laju fotosintesis maka fotosintat yang dihasilkan akhirnya akan memberikan ukuran bertambahnya diameter batang tanaman sengon laut.

\section{Simpulan}

Disimpulkan bahwa pemberian pupuk Bokashi padat berbahan dasar feses babi sangat efektif dapat meningkatkan pertumbuhan tanaman sengon laut dengan bertambahnya tinggi tanaman, jumlah tangkai daun dan diameter batang. Pemberian pupuk Bokashi padat berbahan dasar feses babi pada level $1000 \mathrm{~g}$ (R3) memberikan hasil terbaik pada tinggi tanaman sebesar 12,43 $\mathrm{cm} /$ tanaman; Jumlah tangkai daun 9,93 tangkai/tanaman dan diameter batang sebesar $0,74 \mathrm{~cm} /$ tanaman. Hasil ini lebih baik dibandingkan perlakuan level Bokashi 500 g (R1), 750 g (R2) maupun Kontrol (R0).

Pustaka

Acquaah, G. 2005. Principles of Crop Production. Theory, Technique, and Technology. Pearson, Prentice Hall, New Jersey.

Anggraeni, I., Lelana, N.E. 2011. Penyakit Karat Tumor pada Sengon. Jakarta: Manggala Wanabakti.

Krisnawati, H., Varis, E., Kallio, M., Kanninen, M. 2011. Paraserianthes falcataria (L.) Nielsen, Ecology, Silvicuture and Productivity. CIFOR. Bogor. 
Lingga dan Marsono. 2004. Petunjuk Pengunaan Pupuk. Penebar swadaya. Jakarta.

Mayadewi, N. N. A. 2007. Pengaruh Jenis Pupuk Kandang dan Jarak Tanam Terhadap Pertumbuhan Gulma dan Hasil Jagung Manis. Jurusan Budidaya Pertanian. Vol 26 (4) : 153 - 159 (2007). Fakultas Pertanian Unud, Denpasar.

Musayyanah 2010. Pengaruh Pemberian Pupuk Bokashi terhadap Pertumbuhan Tanaman Sawi (Brassica juncea L.). [Skripsi] Malang: Universitas Islam Negeri Maulana Malik Ibrahim

Sarief, E.S. 2015. Kesuburan dan Pemupukan Tanah Pertanian. Bandung: Pustaka Buana

Steel, R.G.D. and J.H. Torrie. 1995. Prinsip dan Prosedur Statistika: Suatu Pendekatan Biometrik. Penerjemah: Sumantri, B. Gramedia Pustaka Utama, Jakarta.

Siregar IZ, Yunanto T, Ratnasari J. 2008. Prospek Bisnis, Budi Daya, Panen \& Pascapanen Kayu Sengon. Jakarta: Penebar Swadaya.

Poerwowidodo. 2008. Kesuburan dan Pemupukan Tanah Pertanian. Bandung: Pustaka Buana. 